Grabar, P. and Burtin, P. (eds.) (1964). Immuno-electrophoretic Analysis. Elsevier, Amsterdam, London, and New York.

Grouchy, J. de, Royer, P., Salmon, C., and Lamy, M. (1964). Délétion partielle des bras long du chromosome 18. Pathologie et Biologie, 12, 579-582.

Hobbs, J. R. (1968). Immune imbalance in dysgammaglobulinaemia type IV. Lancet, 1, 110-114.

Hobbs, J. R. (1970). Simplified radial immunodiffusion. Association of Clinical Pathologists Broadsheet, $\mathbf{6 8 .}$

Insley, J. (1967). Syndrome associated with a deficiency of part of the long arm of chromosome No. 18. Archives of Disease in Childhood, 42, 140-146.

Lejeune, J., Berger, R., Lafourcade, J., and Réthoré, M.-O. (1966). $\mathrm{La}$ délétion partielle du bras long du chromosome 18 . Individualisation d'un nouvel état morbide. Annales de Génétique, 9 32-38.

Mancini, G., Carbonara, A. O., and Heremans, J. F. (1965). Immunochemical quantitation of antigens by single radial immunodiffusion. Immunochemistry, 2, 235-254.

Nance, W. E., Higdon, S. H., Chown, B., and Engel, E. (1968). Partial E-18 long-arm deletion. Lancet, 1, 303.

Riley, M. and Gochman, N. (1964). Cited in Technicon Method Sheet, No. 56. Technicon Corporation, Terrytown, New York.

Roitt, I. M. and Doniach, D. (1958). Human auto-immune thyroiditis: serological studies. Lancet, 2, 1027-1033.

Stewart, J., Go, S., Ellis, E., and Robinson, A. (1968). IgA and partial deletions of chromosome 18. Lancet, 2, 779.

Wertelecki, W., Schindler, A. M., and Gerald, P. S. (1966). Partial deletion of chromosome 18 . Lancet, 2,641 .

\section{Inherited Pericentric Inversion of a Group D (13-15) Chromosome}

Pericentric inversions of autosomes have been reported infrequently in human subjects, and have been reviewed by Jacobs et al (1967), Weitkamp et al (1969), Crandal and Sparkes (1970), and Wilson et al (1970).

We report a family showing both a pericentric inversion and an unbalanced crossover segregation product from the inversion. The present family shows inheritance through two generations of a structurally abnormal $\mathrm{D}$ chromosome interpreted as a pericentric inversion. The carriers of inversion are phenotypically normal and show no increased frequency of congenital malformation or fetal loss. The propositus described below is the only known individual with an unbalanced crossover segregation product from the inversion.

\section{Case Report}

The pedigree of the family is shown in Fig. 1. The propositus, a male infant (III.3), was the product of a full term pregnancy born to a gravida 3, para 225 -year-old

Received 15 January 1971. mother. The father was 27 years old and there were two older sibs. The mother, father, brother, and sister are all phenotypically normal. There was no family history of mental retardation or congenital malformations. The parents are of Italian ancestry and nonconsanguinous.

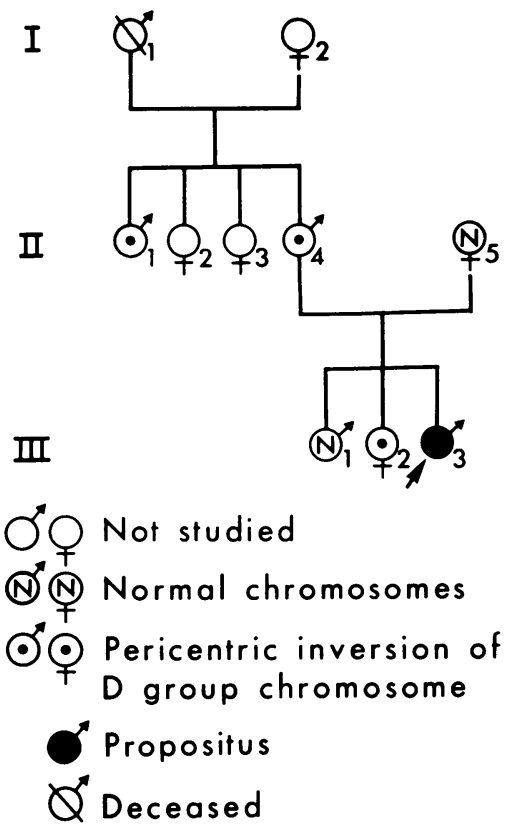

FIG. 1. Pedigree of the family.

The propositus weighed $2890 \mathrm{~g}$ at birth. He had some respiratory distress on the second day of life and radiographs revealed an over-inflated, hyperlucent left lung. Repeat radiological examination on the 7th day revealed equal expansion and aeration of both lungs.

The patient was first admitted to The Hospital for Sick Children at 5 weeks of age because of difficulty in breathing and diarrhoea. He weighed $4.2 \mathrm{~kg}$, was $56 \mathrm{~cm}$ long, and lay in an opisthotonic position. He had an unusual looking round face with slight micrognathia and somewhat low set ears (Fig. 2). There was pitting oedema of both feet. The heart, lungs, and abdomen appeared normal except for a small umbilical hernia. External genitalia were normal male and both testes were descended (Fig. 3).

The infant was treated for gastroenteritis and discharged after 20 days of hospitalization. Since then he has been hospitalized on 4 separate occasions for repeated attacks of pneumonia and respiratory distress.

He was last admitted in June 1969 at 9 months of age because of cardiac failure and severe respiratory distress. He weighed $7.5 \mathrm{~kg}$ (<3rd centile). A loud pansystolic murmur was heard best in the 4th left intercostal space 

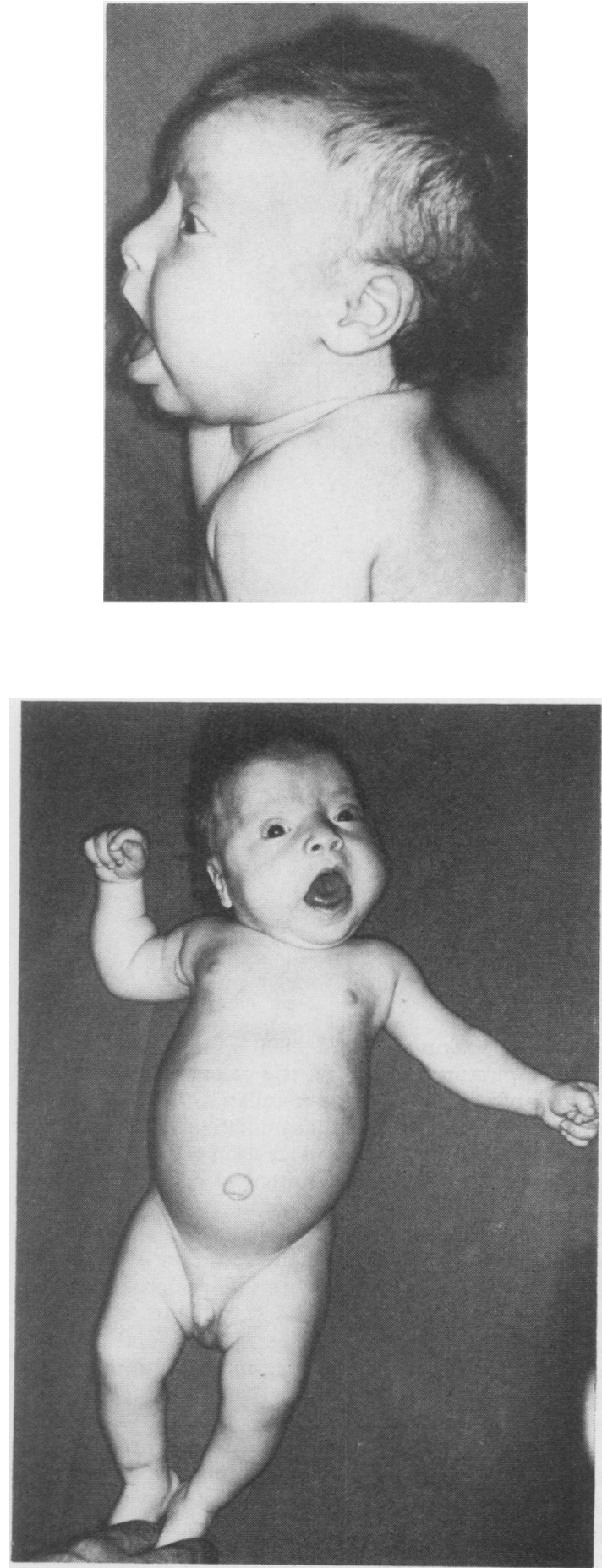

FIGs. 2 and 3. The propositus at the age of 3 months. Note small head, umbilical hernia, and slightly low set ears. along the sternal border and an electrocardiogram $\mathbb{D}$ indicated combined ventricular hypertrophy. Radio- $\underset{\sim}{\mathbb{Q}}$ graphs of the chest revealed pneumonic changes in the right upper and lower lobes.

Laboratory Studies. On each of his several admissions routine tests on blood and urine were normal. $\bar{\omega}$ Values for blood sugar, urea nitrogen, serum electro- $\vec{\nabla}$ lytes, calcium, inorganic phosphorus, and protein bound $\triangle$ iodine were within the normal range. Urinary amino- क acid chromatogram was normal. Repeated sweat $\vec{O}$ electrolyte studies and immunoglobulin estimations were also in normal range. The fetal haemoglobin content was $37 \cdot 4 \%$ at age 2 months and $2.7 \%$ at age 6 months.

Radiographs of skull, spine, and pelvis and intravenous pyelogram, barium enema, and barium swallow showed no abnormalities. Bone age at 6 months of age corresponded to that of a newborn.

Electroencephalograms recorded at 6 and 7 weeks of age were described as 'markedly paroxysmal with slow and sharp wave forms superimposed on a poorly organized background of low voltage activity'. These appearances suggested a diffuse disturbance without precise focal features. The record obtained at 4 months of age was 'considered to be within the broad range of normal though poorly organized for the child's chronological age'.

Cytogenetic Studies. Chromosomal preparations were made twice from peripheral blood lymphocytes and once from skin fibroblasts of the propositus. In both tissues the modal chromosome number was 46 , and on analysis the cells showed a chromosome missing in the 13-15 group and an extra chromosome in $\mathrm{C}$ group. The karyotype was interpreted as $46, \mathrm{XY}, \mathrm{Dp}+$ (Figs. 4 and 5). Fibroblasts were sex chromatin negative.

Chromosomal studies were done on peripheral blood lymphocytes of parents (II.4 and II.5), sibs (III.1 and III.2), and a paternal uncle (II.1) the only relatives available. The karyotypes of the mother (II.5) and one sib (III.1) were structurally and numerically normal. The cells of the father (II.4), paternal uncle (II.1), and one sib (III.2) all had 46 chromosomes and on analysis showed a chromosome missing in the 13-15 group and an additional slightly submetacentric chromosome resembling No. 16 in size (Fig. 5). These karyotypes were interpreted as a pericentric inversion of a $D$ group chromosome (D inv). A careful examination of many metaphases failed to show satellites on the 'abnormal D chromosomes'. Autoradiographic studies and genetic marker studies were not performed as the parents refused to cooperate further. The chromosome counts and karyotype diagnosis in the patient and his relatives are summarized in Table I.

Chromosome measurements of normal D, D inv, and No. 16 were carried out on 10 suitable cells from three carriers and are summarized in Table II. Cells of the propositus were not included as the additional $\mathrm{C}$ group chromosome could not always be differentiated from some of the other $\mathrm{C}$ group chromosomes. Prints were .

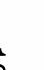

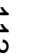
. co N 


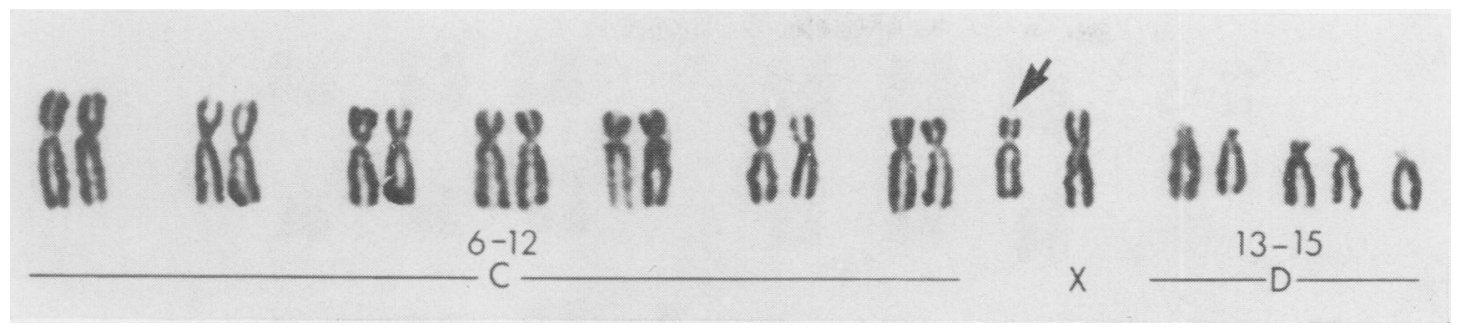

FIG. 4. Partial karyotype of the propositus. Note only 5 normal members in Group D and an extra chromosome in Group C (arrow).

made on $20.3 \times 25.4 \mathrm{~cm}$ photographic paper and both chromatids of the above mentioned chromosomes were measured by counting the notches on the wheel of a map measurer. The results suggest that the $\mathbf{D}$ inv chromosome is slightly submetacentric and no bigger than the normal D chromosomes.
Dermatoglyphs of the propositus were normal.

\section{Discussion}

The karyotype of the propositus was interpreted as $46, \mathrm{XY}, \mathrm{Dp}+$. The possibility of $\mathrm{D} / \mathrm{G}$ translocation Down's syndrome, was ruled out on

TABLE I

CHROMOSOME COUNTS AND KARYOTYPE DIAGNOSIS IN THE PATIENT AND HIS RELATIVES

\begin{tabular}{|c|c|c|c|c|c|c|c|}
\hline Subject* & $\begin{array}{c}\text { Tissue } \\
\text { Examined }\end{array}$ & $<45$ & 45 & 46 & $\begin{array}{l}\text { Cells } \\
\text { Counted }\end{array}$ & $\begin{array}{l}\text { Metaphases } \\
\text { Analysed }\end{array}$ & Karyotype \\
\hline $\begin{array}{l}\text { III.1 } \\
\text { III.2 } \\
\text { III.3 } \\
\text { II.1 } \\
\text { II. } 4 \\
\text { II. } 5\end{array}$ & $\begin{array}{l}\text { Blood } \\
\text { Blood } \\
\text { Blood } 1 \\
\text { Blood } 2 \\
\text { Skin } \\
\text { Blood } \\
\text { Blood } \\
\text { Blood }\end{array}$ & $\begin{array}{l}\overline{-} \\
\overline{-} \\
\bar{z} \\
\overline{6} \\
1\end{array}$ & $\begin{array}{l}2 \\
4 \\
\overline{1} \\
- \\
- \\
4 \\
1\end{array}$ & $\begin{array}{l}38 \\
46 \\
30 \\
34 \\
35 \\
30 \\
34 \\
28\end{array}$ & $\begin{array}{l}40 \\
50 \\
30 \\
35 \\
35 \\
30 \\
44 \\
30\end{array}$ & $\begin{array}{l}15 \\
50 \\
30 \\
35 \\
35 \\
30 \\
44 \\
15\end{array}$ & 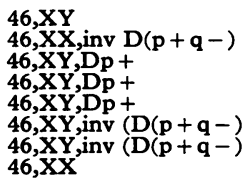 \\
\hline
\end{tabular}

* See pedigree (Fig. 1).

TABLE II

MEASUREMENT OF D GROUP AND NO. 16 CHROMOSOMES

\begin{tabular}{|c|c|c|c|c|c|c|c|c|c|c|}
\hline \multirow{2}{*}{ Subject } & \multirow{2}{*}{ Cell No. } & & \multicolumn{6}{|c|}{ D group Chromosomes } & \multicolumn{2}{|c|}{ No. 16} \\
\hline & & & 1 & 2 & 3 & 4 & 5 & $D$ inv & 1 & 2 \\
\hline II.1 & $\begin{array}{l}1 \\
2 \\
3\end{array}$ & $\begin{array}{l}\text { TL* } \\
\text { AR† } \\
\text { TL } \\
\text { AR } \\
\text { TL } \\
\text { AR }\end{array}$ & $\begin{array}{l}36 \\
33 \\
24\end{array}$ & $\begin{array}{l}34 \\
33 \\
24\end{array}$ & $\begin{array}{l}33 \\
32 \\
23.5\end{array}$ & $\begin{array}{l}33 \\
31.5 \\
23.5\end{array}$ & $\begin{array}{l}32 \\
30 \\
21\end{array}$ & $\begin{array}{c}33 \\
0.94 \\
32 \\
0.88 \\
26 \\
0.85\end{array}$ & $\begin{array}{c}33 \\
0.65 \\
32 \\
0.60 \\
24 \\
0.71\end{array}$ & $\begin{array}{c}32 \\
0.60 \\
32 \\
0.60 \\
24 \\
0.60\end{array}$ \\
\hline II.4 & $\begin{array}{l}4 \\
5 \\
6\end{array}$ & $\begin{array}{l}\text { TL } \\
\text { AR } \\
\text { TL } \\
\text { AR } \\
\text { TL } \\
\text { AR }\end{array}$ & $\begin{array}{l}26 \\
26 \cdot 5 \\
25\end{array}$ & $\begin{array}{r}23.5 \\
25.5 \\
23.5\end{array}$ & $\begin{array}{r}23.5 \\
24.5 \\
23.5\end{array}$ & $\begin{array}{l}23 \\
23 \\
23\end{array}$ & $\begin{array}{l}22 \\
22.5 \\
22.5\end{array}$ & $\begin{array}{c}22 \\
0.91 \\
24 \\
0.91 \\
24 \\
0.84\end{array}$ & $\begin{array}{c}23 \\
0.66 \\
21.5 \\
0.65 \\
23 \\
0.66\end{array}$ & $\begin{array}{c}23 \\
0.58 \\
21.5 \\
0.60 \\
23 \\
0.58\end{array}$ \\
\hline III. 2 & $\begin{array}{r}7 \\
8 \\
9 \\
10\end{array}$ & $\begin{array}{l}\text { TL } \\
\text { AR } \\
\text { TL } \\
\text { AR } \\
\text { TL } \\
\text { AR } \\
\text { TL } \\
\text { AR }\end{array}$ & $\begin{array}{l}34 \cdot 5 \\
31 \cdot 5 \\
31 \cdot 5 \\
36\end{array}$ & $\begin{array}{l}33 \\
30 \\
31 \\
34\end{array}$ & $\begin{array}{l}32 \\
30 \\
28 \cdot 5 \\
34\end{array}$ & $\begin{array}{l}29 \cdot 5 \\
29 \cdot 5 \\
28 \cdot 5 \\
32\end{array}$ & $\begin{array}{l}29 \\
28 \\
27 \\
31\end{array}$ & $\begin{array}{c}29.5 \\
0.96 \\
32 \\
0.88 \\
29 \\
1.0 \\
32 \\
0.88\end{array}$ & $\begin{array}{c}20 \\
0.66 \\
30 \\
0.66 \\
28 \\
0.64 \\
30 \\
0.66\end{array}$ & $\begin{array}{c}29.5 \\
0.61 \\
28 \\
0.64 \\
28 \\
0.64 \\
29 \\
0.61\end{array}$ \\
\hline
\end{tabular}

* $\mathrm{TL}=$ total length (average of two measurements) expressed as numbers of map measuring notches.

$+\mathrm{AR}=$ arm ratio (short arm/long arm). 


\section{II-5 \\ Of of th th \\ ลัด หล่ \\ If it 0 \\ aิ यั แล \\ II-4 \\ id 40 \\ - \\ 8 \\ 88 id แa \\ at \\ it \\ a \\ 8 \\ 6888 \\ on \\ II- \\ of \\ oo \\ b 8 \\ ix bro at

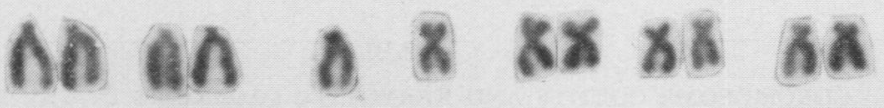

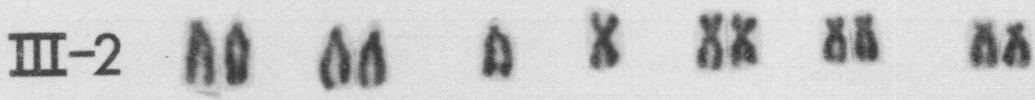

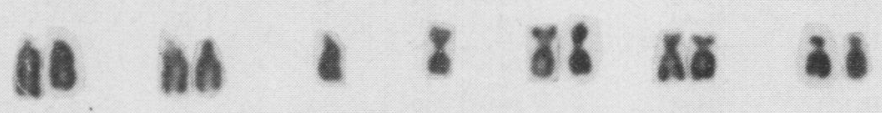

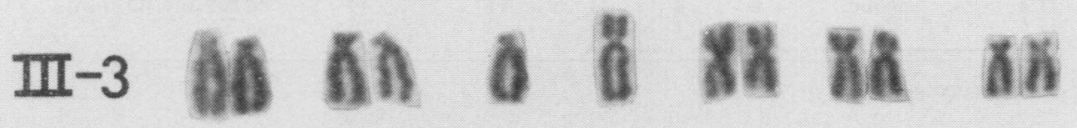

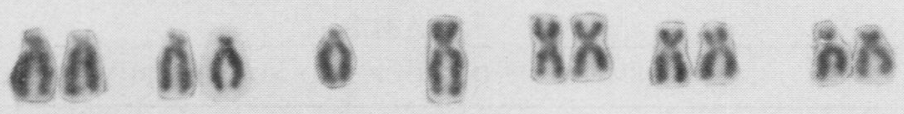

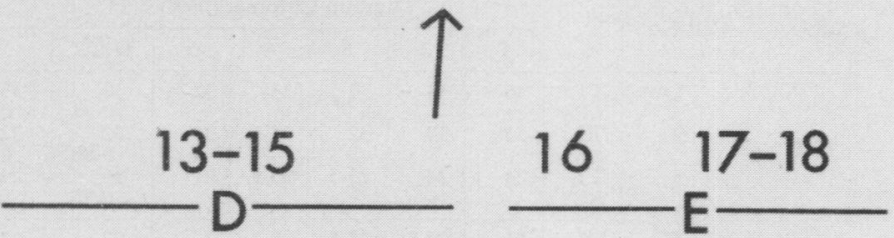

FIG. 5. D and $\mathbf{E}$ group chromosomes of propositus and his relatives, shown with numbers referring to position on pedigree given in Fig. 1. Arrow indicates the abnormal chromosomes.

grounds of clinical features and dermatoglyphics; an increase in the length of the short arm of a $D$ group chromosome was ruled out because neither sibs nor parents had such an aberrant chromosome. Translocation from one of the other chromosomes, though possible, is unlikely in view of the absence of other karyotype anomalies.
The abnormal chromosome in the propositus differs from that of his father and other carriers in the family (Fig. 5) and is assumed to represent a product of crossover during meiosis in the carrier father.

The probability of a chiasma occurring in the inversion loop at meiosis is related to the size of the 


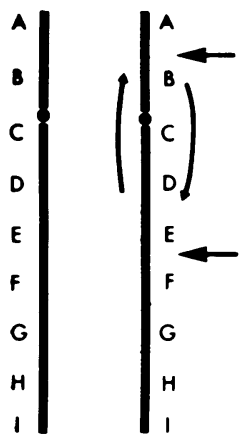

A

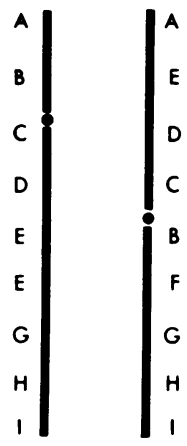

B

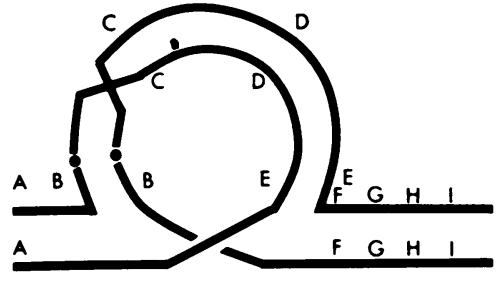

C

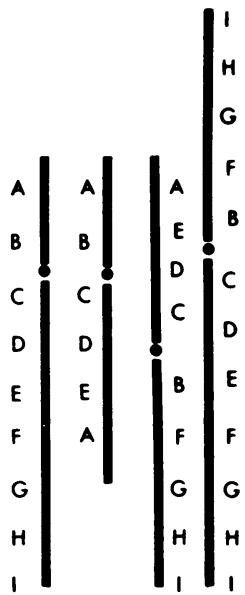

D

FIG. 6. A. Normal D group pair with sites of pericentric breaks. B. Pericentric inversion. C. A single chiasma in an inversion heterozygote, during meiosis (only two strands are shown). D. Four products of meiosis arising from a single crossover in inversion loop.

inversion loop; with a small loop a chiasma may only rarely be found.

Let us consider a pair of D group chromosomes differentiated as ABCDEFGHI (Fig. 6A), the centromere being between $B$ and $C$. When the breaks are pericentric (between $A$ and $B$, and $E$ and F) and the middle piece inverted relative to the end pieces, it undergoes exchange unions with them and pericentric inversion results (Fig. 6B). Note that an inversion is an euploid rearrangement, and is of no phenotypic consequence as exhibited by II.1, II.4, and III.2 in this pedigree.

At meiosis in the father (II.4) of the propositus a single chiasma, such as between $\mathrm{B}$ and $\mathrm{C}$ (Fig. $6 \mathrm{C}$ ) produces 4 monocentric strands (Fig. 6D)-two are non-crossovers (one with and one without the inversion, and these are the strands of the tetrad not included in Fig. 6C), one has a duplication for A and a deficiency for FGHI, the other has a deficiency for $A$ and a duplication for FGHI. The gamete containing the strand which has a deficiency of A and a duplication of FGHI, when fertilized by a gamete containing normal member of $\mathrm{D}$ group chromosome could result into a chromosomal picture as shown by the propositus.

We assume that I.1 or I.2 must be a carrier of Dinv chromosome as II.1 and II.4 are carriers.

This family is the third reported example of a pericentric inversion of a group D chromosome.

Cohen, Capraro, and Takagi (1967), reported a case of a 38-year-old white female with secondary amenorrhoea and minimal stigmata of gonadal dysgenesis. Her karyotype was abnormal and was interpreted as a pericentric inversion involving an autosome of group D. On autoradiographic studies they concluded that the marker chromosome belonged to the late-replicating pair of the D group. The other members of the family, except for the father, could not be studied and hence the inheritance could not be established.

Crandal and Sparkes (1970) reported a case of a 9-year-old boy with short stature and minimal speech defect. His karyotype was interpreted as a pericentric inversion of a group $D$ chromosome which on autoradiographic studies was thought to be a No. 15 chromosome. Family studies demonstrated its presence in 8 other individuals, all of whom were phenotypically normal.

A presumptive inversion in a group D chromosome was reported in a clinically normal fatherdaughter pair by Chandra and Hungerford (1963). In their case satellites were retained in the inverted chromosome. However, the aberrant chromosome described may be an example of increase in length of the short arm of an acrocentric chromosome; such variations in length of the short arm of a D group chromosome with no other detectable alteration of the karyotype are common (Court Brown et al, 1966; Lord and Cooke, 1967).

The only report that offers information most pertinent to our family is that of Wilson et al (1970). They recently reported a family showing both a 
pericentric inversion and an unbalanced crossover segregation product from the inversion. However, the structurally abnormal chromosome involved is No. 4 and not a D chromosome.

\section{Summary}

A non-satellited, slightly submetacentric chromosome replacing one of the members of the 13-15 group was found in the apparently healthy father, paternal uncle, and sister; their karyotypes were otherwise normal. The aberrant chromosome is interpreted as being a result of pericentric inversion. One of the $\mathrm{D}$ chromosomes of the propositus was abnormally large and is assumed to represent duplication of a part of the long arm as a result of single crossover during meiosis in the father.

Rawatmal B. Surana* and Patrick E. Conen

The Department of Pathology, University of Toronto, and the Department of Pathology and The Research Institute, The Hospital for Sick Children, Toronto, Canada

\section{REFERENCES}

Chandra, H. S. and Hungerford, D. A. (1963). An aberrant autosome (13-15) in a human female and her father, both apparently normal. Cytogentics, 2, 34-41.

Cohen, M. M., Capraro, V. J., and Takagi, N. (1967). Pericentric inversion in a group D chromosome (13-15) associated with amenorrhoea and gonadal dysgenesis. Annals of Human Genetics, 30, 313-323.

Court Brown, W. M., Jacobs, P. A., Buckton, K. E., Tough, I. M., Kuenssberg, E. V., and Knox, J. D. E. (1966). Chromosome Studies on Adults. Eugenics Laboratory Memoirs 42. Galton Laboratory, Cambridge University Press, London.

Crandal, B. F. and Sparkes, R. S. (1970). Pericentric inversion of a number 15 chromosome in nine members of one family. Cytogenetics, 9, 307-316.

Jacobs, P. A., Cruickshank, G., Faed, M. J. W., Frackiewicz, A., Robson, E. B., Harris, H., and Sutherland, I. (1967). Pericentric inversion of a group $C$ autosome: a study of three families. Annals of Human Genetics, 31, 219-230.

Lord, P. M. and Cooke, P. (1967). A familial variant chromosome in the 13-15 group. Fournal of Medical Genetics, 4, 114-116.

Weitkamp, L. R., Janzen, M. K., Guttormsen, S. A., and Gershowitz, H. (1969). Inherited pericentric inversion of chromosome number two: a linkage study. Annals of Human Genetics, 33, 53-59.

Wilson, M. G., Towner, J. W., Coffin, G. S., and Forsman, I. (1970). Inherited pericentric inversion of chromosome No. 4. American fournal of Human Genetics, 22, 679-690.

This study was aided by funds from the Medical Research Council of Canada (MA 2550). Address reprint requests to P.E.C.: Department of Pathology, The Hospital for Sick Children, 555 University Avenue, Toronto 101, Ontario, Canada.

* Present address: Department of Pediatrics, Howard University College of Medicine and Freedmen's Hospital, 6th and Bryant Sts, NW, Washington, DC 20001, USA.

\section{A 45,XX,21- Child: Attempt at a Cytological and Clinical Inter- pretation of the Karyotype}

Of the chromosomal diseases occurring in man, $\frac{\bar{\sigma}}{\bar{\omega}}$ G-group abnormalities are among the most fre- $\frac{\vec{\sigma}}{\vec{\sigma}}$

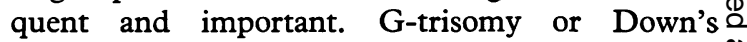
syndrome was the first chromosomal error described in man (Lejeune, Gautier, and Turpin, $\overrightarrow{0}$ 1959). Other abnormalities of the $G$ group are translocations, deletions of the short and long $\vec{\omega}$ arms ( $\mathrm{Gp}-$ and $\mathrm{Gq}-$ ), rings (Gr), and mixoploidy comprising monosomic cell lines.

The present paper is a report on an infant with 6 minor somatic anomalies and signs of mental retardation. A chromosome No. 21 is missing in $\overrightarrow{\mathcal{F}}$ all the cells studied from the blood, bone marrow, and skin. Three other cases of apparent Gmonosomy have been described in the literature $\bar{z}$ (Thorburn and Johnson, 1966; Al-Aish et al, 1967; Hall, Fredga, and Svenningsen, 1967).

Autoradiographic and fluorescence studies gave $\vec{\varphi}$ unequivocal results with regard to the $\mathrm{G}$ group $N$ chromosome involved, the missing chromosome being No. 21 .

\section{Case Report}

Family History. The child is the younger of two sibs born to nonconsanguineous parents. The father and mother were aged 25 and 22 , respectively, at her 3 birth. The parents and the brother are phenotypically normal and healthy. The mother had been taking an oral contraceptive at the time of conception.

The grandmother of the patient has two brothers who have emigrated to Canada. One of these is said to have a mongoloid child, the other also has a retarded child.

Case History. As a newborn baby the proposita was referred for cytological examination. Her birth weight was low and she showed a peculiar facies with small mandible, high palate, flexion deformity of the fingers, and a short trunk.

She was born at term after an uneventful pregnancy and normal delivery; birth weight was $2350 \mathrm{~g}$ and length $45 \mathrm{~cm}$. After birth the child was slightly blue and her temperature fell below normal. She was given oxygen for the first few days and made a good recovery.

The child was found to have congenital dislocation of the hips and some signs of arthrogryphosis. She was transferred to Aurora Hospital at the age of 3 days.

Physical examination. The child was small and pale, with signs of general dysplasia. Some moderately

Received 1 June 1971. 